\title{
PRAVNA ZNANOST: KANTOROWICZEVA DIOBA NA DISCIPLINE ILI FUNKCIJE?
}

Pokrovčeva knjiga Slobodno stvaranje prava: Herman U. Kantorowicz i slobodnopravni pokret (2018) nameće pitanje izraženo naslovom ovog rada na koje rad odgovara u tri koraka: prvo, pretpostavkom da je pitanje odgovorivo samo idealnim tipovima pravnih disciplina / funkcija; drugo, upućivanjem na kontekst Kantorowiczevih gledišta, osobito na objavu presuda; tréce, ocjenom da je Kantorowicz podijelio pravnu znanost u prepletene funkcije a ne u odvojene discipline. $U$ tu svrhu rad nudi idealne tipove disciplina i funkcija pravne dogmatike, pravne historije, pravne teorije i, kao najsloženiji i najkorisniji skup funkcija, pravnopolitičku analizu. Pretpostavka je, koja se ne dokazuje, da ne postoji ni oštra granica između pravne znanosti i susjednih znanosti: sociologije, ekonomije, psihologije, filozofije.

Ključne riječi: Hermann U. Kantorowicz, pravna znanost, pravna dogmatika, pravna historija, pravna teorija, pravna politika

(0.l) Teorijski problem ovog prinosa sažet je njegovim naslovom. Potpunije određen izraziv je sljedećim pitanjem: je li Kantorowiczeva dioba znanosti o pravu, osobito ona u šest dijelova, naime, na opću pravnu znanost, pravnu dogmatiku, pravnu historiju, sociologiju prava, filozofiju prava i pravnu politiku ${ }^{1}$, dioba u samostalne znanosti ili u funkcije jedinstvene pravne znanosti?

* Dr. sc. Ivan Padjen, redoviti profesor u t. z. u m.; Pravni fakultet Sveučilišta u Rijeci, Hahlić 6, Rijeka; Fakultet političkih znanosti Sveučilišta u Zagrebu, Lepušićeva 6, Zagreb; ivan.l.padjen@gmail.com;

ORCID ID: orcid.org/ 0000-0001-7606-2337

1 Kantorowicz, H. U., Rechtswissenschaft und Soziologie, Mohr, Tübingen, 1911.; Idem, Staatsauffassungen: Eine Skize, Jahrbuch fuer Soziologie, Bd. 1, 1925., str. 101 - 114. 
(0.2) U Hrvatskoj se pravno istraživanje uči i dograđuje čineći, bez izričite metodologije pravne znanosti (metodologije prava i društvenih znanosti to ni po nazivu ni po sadržaju nisu). Stoga nije jasno dvoje: koja su mjerila znanstvenosti pravne znanosti, odnosno pravnih znanosti?; napose, postoje li pravnoznanstvena mjerila istraživanja i savjetovanja de lege ferenda, koja su potrebna ne samo za izradu propisa i ugovora nego i za upravnu i sudsku primjenu prava, koja je uvijek i stvaranje prava?

(0.3) Knjiga Zorana Pokrovca Slobodno stvaranje prava: Hermann U. Kantorowicz i slobodnopravni pokret (Zagreb, Naklada "Breza", 2018., 815 str.), povod je a i pretpostavka dijela ovog prinosa utoliko što je uzeta za mjerodavno tumačenje Kantorowiczevih gledišta. Knjiga je svojim sadržajem - iako ne i jezikom (hrvatskim) kojim je napisana - izvorni doprinos pravnoj znanosti u internacionalnim razmjerima; u hrvatskoj pravnoj znanosti pregledni je rad enciklopedijske važnosti te najučenija hrvatska rasprava iz teorije prava i države pisana nakon II. svjetskog rata. Izvorni je rad, prvo, po tom što postavlja i rješava važan i složen problem, koji je i danas predmet internacionalnog interesa ${ }^{2}$, a to je Kantorowiczev doprinos teoriji slobodnog stvaranja prava u kontekstu istovrsnog pokreta; i drugo, po nakani i - koliko je moguće razabrati onome tko nije sam istraživao probleme knjige - također po dometu, a to je da iscrpno prikaže i ocijeni predmete istraživanja, na što upućuje već opseg od 1322 autorske stranice teksta i više od 500 korištenih izvora. Primarni predmet, tj. izvori, Kantorowiczevi su radovi, i to oni koji su važni za teoriju slobodnog stvaranja prava, te svi važniji radovi ostalih pripadnika pokreta. Sekundarni predmet, tj. izvori, svi su znanstveni radovi o primarnim predmetima pisani do vremena završetka rukopisa 1995. godine, a to su istodobno i svi monografski radovi o primarnim izvorima objavljeni do danas. Knjiga je najučeniji doprinos hrvatskoj teoriji prava i države po iscrpnosti, tj. po tom što usporedno prikazuje i ocjenjuje svako važnije stajalište primarnih i sekundarnih izvora.

(0.4) Zadaća je ovog prinosa trostruka: (I) da ukratko izloži vlastite - no samo najnužnije - pretpostavke; (2) da pobliže izloži, polazeći od Pokrovčeve knjige, pretpostavke i uvjete Kantorowiczeve diobe znanosti o pravu, i to (2.l) Kantorowiczevo shvaćanje pravne povijesti kao kretanja između formalizma i finalizma, (2.2) obrazlaganja i objave sudskih presuda kao uvjeta suvremenog kretanja, (2.3) filozofijske pretpostavke diobe; (3) da Kantorowiczevu diobu ocijeni i dopuni, pokazujući da je to dioba jedinstvene pravne znanosti u sljedeće

2 Npr. "Hermann Kantorowicz (1877-1940): the battle for legal science" conference, University of Helsinki, (October 25th-26th 2018); https://www.helsinki.fi/en/news/ society-economy/hermann-kantorowicz-1877-1940-the-battle-for-legal-scienceconference (1. prosinca 2018.). 
funkcije: (3.2) pravnu dogmatiku, (3.3) pravnu historiju, (3.4) pravnu teoriju i (3.5) pravnu politiku. Pretpostavka je prinosa da između pravne znanosti i drugih znanosti - osobito sociologije, ekonomije, psihologije, filozofije - postoji samo meka granica, no ta se pretpostavka zbog ograničenog opsega prinosa ne dokazuje.

\section{(1) Pretpostavke}

Nosive pretpostavke ovog prinosa sukladne su Kantorowiczevima o temeljima pravne znanosti (infra 2.3) te glase: svaka ljudska tvorba, tj. djelovanje i učinak, jedinstvena je i neponovljiva, ako već ne po svom sastavu (čije poimanje, osobito odnosa duha i tijela, mijenjamo), po interesu kojim je spoznajemo; stoga ljudske tvorbe spoznajemo razumijevanjem i objašnjavanjem po sličnosti; iz istog su razloga pojmovi o ljudskim tvorbama, tj. pojmovi humanističkih i društvenih znanosti (npr. društvo, zajednica, djelatnik, djelovanje, pravilo, predaja, gubitak itd.) idealni tipovi.

(1.l) Ovdje su važne sljedeće značajke idealnog tipa: ${ }^{3}$ nema istinosnu vrijednost, tj. nije ni istinit ni neistinit jer njegova istinitost ne može biti provjerena usporedbom s pojavama na koje se odnosi, a ne može zbog toga što pojave na koje se odnosi nisu jednake nego slične; služi za prepoznavanje i opisivanje te uspoređivanje društvenih pojava; stoga ima koristonosnu vrijednost, tj. više je ili manje spoznajno koristan, ovisno o tomu u kojoj mjeri omogućuje prepoznadbu, opis i usporedbu pojava na koje se odnosi; tek nakon što je ljudska tvorba takvim razumijevanjem spoznata, njezin postanak može biti objašnjen naturalistički, tj. prilagodbom okolini, odnosno svrhovitošću, i općim zakonima, odnosno djelatnom uzročnošću ${ }^{4}$; tek nakon što je tvorba barem u nekoj mjeri naturalistički objašnjena, može biti smisleno (jer ultra posse nemo tenetur) propisana.

(1.2) Shodno izloženim pretpostavkama, ne postoji, na način na koji to postoji, npr. stol ili fakultet, niti jedna od disciplina ili funkcija na koju upućuje Kantorowiczeva dioba. One su samo nazivi mnoštva više ili manje sličnih tvorbi

3 Weber, M., Die 'Objektivität' sozialwissenschaftlicher und sozialpolitischer Erkenntnis, u: Idem, Gesammelte Aufsätze zur Wissenschaftslehre, 3. Aufl., hrsg. v. Winckelmann, J. Mohr \& Paul Siebeck, Tübingen, 1968., str. 146 - 214, osobito 190 - 211. O razlici idealnih tipova, koji su svojstveni društvenim znanostima, i modela, koji su svojstveni prirodnim znanostima, vidi u: Saegesser, B., Der Idealtypus Max Webers und der naturwissenschaftliche Modellbegriff, Druckerei Birkhaeuser, Basel, 1975., osobito str. $155-172$.

4 Npr. Apel, K.-O., Analytic Philosophy of Language and the Geisteswissenschaften, Reidel, Dordrecht, 1968., str. 23. 
različitih djelatnika od kojih neke jesu, a neke nisu nazivane "pravna dogmatika", "pravna historija" i sl. Stoga je ovaj prinos oblikovanje idealnih tipova tih disciplina ili funkcija, no takvo koje u najvećoj mjeri preuzima njihove odredbe dane od utjecajnih autora, te istraživanje međusobnih odnosa tih idealnih tipova. Spoznajnu plodnost tog pristupa omogućuje, među ostalim, srodnost nosivih pretpostavki (supra 1. - 1.1) i Kantorowiczevih pretpostavki (infra 2.3) te bliskost hrvatskoj pravnoznanstvenoj praksi.

\section{(2) Kantorowiczeva dioba}

(2.1) Kantorowiczeva dioba znanosti o pravu pretpostavlja objašnjenje kretanja zapadnog prava. S obzirom na to da sam Kantorowicz ta dva izraza određuje kontekstualno, ovaj prinos pretpostavlja sljedeće Pokrovčevo tumačenje:

Kantorowicz smatra da se u povijesti pravoznanstva, iza stalno mijenjajućih se formi $i$ imena, uvijek iznova otvara jednaka suprotnost, da se ono, kao klatno, stalno krée izme¿u formalističkoga i finalističkoga pola, težeći, u njegovo doba, ponovno k finalističkom. Formalistički smjer polazi od formuliranog pravnog stava, najčešce zakonskoga teksta, pitajući se kako tumačiti tekst pa da to odgovara volji koja je formulirala tekst, a zatim se - prividno postupajući čisto logički - iz te volje stvara zatvoreni sistem pojmova i stavova iz kojeg navodno rezultira svaka odluka. Finalistički smjer umjesto od knjige, polazi od "smisla" zbiljskosti, od svrha i potreba socijalnoga, duhovnoga, ćudorednoga života, koje smatra vrlo vrijednima; prema tim svrhama rješava dvojbena pitanja formalnoga prava $i$ ispunjava njegove nepobrojive praznine. Ili, jezgrovito formulirano: formalistički smjer traži smisao za postojeću formulu, finalistički formulu za "zadati" smisao.

Točnost Pokrovčeva tumačenja potvrđuje Kantorowiczeva vlastita ocjena zastranjivanja ne samo formalizma nego i finalizma. Naime, našao je pretjeranim i stoga neprihvatljivim američki pravni realizam njegova vremena, $i$ to ne krajnji nego umjereni, onaj Karla Llewellyna. ${ }^{6} \mathrm{U}$ svjetlu tog protivljenja krajnosti, ovdje je moguće iznijeti pretpostavku da su se današnja hrvatska pravna znanost i hrvatsko pravo približili suprotnoj krajnosti. Na to upućuje za znanost pitanje o istraživanjima i savjetovanjima de lege ferenda (supra 0.2), a za pravo ocjena objave sudskih odluka (infra 2.2.4).

5 Pokrovac, Z., Slobodno stvaranje prava: Hermann U. Kantorowicz i slobodnopravni pokret, Breza, Zagreb, 2018, str. 73 - 74, upućujući na Kantorowicz, H. U., Die Epochen der Rechtswissenschaft, Die Tat, Bd. 6, H. 4, 1914., str. 345 - 361; citirano po Idem, Rechtshistorische Schriften, hrsg. v. Coing, H.; Immel, G., Mueller, Karlsruhe, 1970.

6 Kantorowicz, H. U., Some Rationalism about Realism, Yale Law Journal, vol. 43, no. 8, 1934., str. $1240-1253$. 
(2.2) Zaokret u pravcu finalizma, koji je počeo na prijelazu u 20. stoljeće u Njemačkoj $^{7}$ i Francuskoj $^{8}$ te Sjedinjenim Američkim Državama ${ }^{9}$, potaknut je u velikoj mjeri obrazlaganjem i objavljivanjem sudskih odluka. Pokrovac na njega višekratno upozorava. ${ }^{10}$ Tako ističe

važnost jednoga u radovima o slobodnopravnom pokretu manje-više zapostavljenog problema, koji bi se mogao formulirati u obliku pitanja: koliko početkom stoljeća sve razvijenija praksa objavljivanja sudskih presuda i načini njihova objavljivanja djeluju kao faktori koji pridonose slobodnopravnoj kritici sudstva? ... Je li, kao što tvrdi Düringer, način objavljivanja presuda zaista onemogućavao pouzdan uvid u sudsku praksu? ${ }^{11}$

Kao potporu prvom dijelu pitanja Pokrovac citira izjavu Karla Schneidera danu još 1911. godine da "engleski precedenti nemaju više privlačnosti jer se suci u Njemačkoj već sada guše u mnoštvu objavljenih sudskih odluka". ${ }^{2}$ Kao potporu drugom dijelu navodi ocjenu Albrechta Mendelssohna Bartholdyja da se slobodnopravni pokret "stalno hrani na publiciranim odlukama najviših sudova". ${ }^{13}$

(2.2.1) Objava obrazloženja presuda omogućuje procjenu u kojoj mjeri su presude primjena, a u kojoj, uslijed pravnih praznina, stvaranje prava. Pokrovac navodi da je u njemačkoj pandektistici, tj. znanosti privatnog prava obnovljenoj od Savignyja, vladao nauk o nepostojanju praznina. ${ }^{14}$ Osporio ju je slobodnopravni pokret. Tako je Kantorowicz, koji je i najutjecajniji pripadnik pokreta, ustvrdio da se sva zbilja ne može objasniti iz jednog načela i da je iluzija

7 Pokrovac, op. cit. u bilj. 5, t. 9. "Slobodnopravni pokret, ili: k nepoznanici koja traje", str. 479 - 738.

8 Pokrovac, op. cit. u bilj. 5, t. 9.8.1. "F. Gény i slobodnopravni pokret", str. 725 - 29. Vidi osobito: Gény, F., Méthode d'interprétation et sources en droit privé positif, 2 t., lere ed. 1899; 2ème ed. 1919, réimpr. L.G.D.J., Paris, 1954. Vidi usporedbu zakonodavnog i sudskog stvaranja prava u kontinentalnoj Europi i SAD-u u: Mayda, J., François Gény and Modern Jurisprudence, Louisiana State University Press, Baton-Rouge, 1978.

9 Pokrovac, op. cit. u bilj. 5, t. 9.8.2. "Utjecaj slobodnopravnog pokreta na američku jurisprudenciju”, str. 730 - 738. Ukratko o američkome pravnom realizmu Leiter, B., American Legal Realism, u: Patterson, D. (ed.), Guide to a Companion to Philosophy and Legal Theory, $2^{\text {nd }}$ ed., Wiley-Blackwell, Chichester, UK, 2010., str. 249 - 266. Kritički iz europskog, odnosno njemačkog nasljeđa Casper, G., Juristischer Realismus und politische Theorie im amerikanischen Rechtsdenken, Duncker \& Humblot, Berlin, 1967.

10 Npr. Pokrovac, op. cit. u bilj. 5, t. 7.3., str. 298.

11 Ibid., str. 648 - 649 .

12 Ibid., str. 648, bilj. 3.

13 Ibid., str. 648, bilj. 2.

14 Ibid., t. 6.4. "Praznine/potpunost prava", str. 242 - 254. 
vjerovati u potpunost spoznaje, tj. da u spoznaji nužno postoje praznine. ${ }^{15}$ Tako su i u pravu praznine neizbježne. Rijetki su pravni pojmovi koji imaju čvrsto određene pojmovne jezgre. Većina ih ima samo "plivajuće obrise”. Uslijed toga, sredstva tumačenja zakona nisu dovoljna za popunjavanje pravnih praznina. Popunjavane su oduvijek slobodnim pravom. Takvo popunjavanje nije jednostavno popunjavanje nego, nesporno, preinačavanje zakona. ${ }^{16}$ Prema Pokrovcu,

Kantorowicz samo jednom jasno kaže, onoliko koliko može biti jasna negativna definicija, što jest slobodno pravo: "slobodno pravo jest sve pravo koje nije uobličeno pravo (förmliches Recht), to znači zakon ili formulirano običajno pravo". ${ }^{17}$ Ponešto je ipak izvjesno: i slobodno pravo je pravo. Njegove su karakteristike: 1) neuobličenost...; 2) važi neovisno o državnoj moći...; 3) povijesnost...; 4) pozitivnost...; 5) relativna neovisnost od državnoga prava...; 6) spontanost $i$ intuitivnost. ${ }^{18}$

(2.2.2) Spoznaja da sudska praksa nije jednostavno primjena zakona nego i stvaranje prava proširila je izvore, s jedne strane, samom sudskom praksom i, s druge, izvorima različitima i od zakona i od sudske prakse. Ako se pravo ne sastoji samo od zakona nego i presuda, pravo može postojati samo ako je veza između njih predmetom stalnog ispitivanja i ocjenjivanja, tj. toga što se naziva pravnim rasuđivanjem. Posljednjih pol stoljeća postaje središnjim dijelom europske filozofije prava. ${ }^{19}$ Izučavanje pravnog rasuđivanja pokazuje da pravo ne može biti samo skup pravila, koja uređuju djelovanja, nego da uključuje također vrijednosti, tj. ciljeve djelovanja, i funkcije, tj. učinke djelovanja. ${ }^{20}$ Taj

15 Ibid., str. 245, upućuje na Kantorowicz, H. U., Zur Theorie des Sozialliberalismus, Schmollers Jahrbuch, Bd. 28, 1904., str. 673 - 682, citirano na str. 676 - 677.

16 Pokrovac, op. cit. u bilj. 5, str. 247, citira Kantorowicz, H. U., Der Kampf um die Rechstwissenschaft. Von Gnaeus Flavius, Winter, Heidelberg, 1906., str. 14.

17 Pokrovac, op. cit. u bilj. 5, str. 224, citira Kantorowicz, H. U., Methodenreform und Justizreform, Deutsche Richterzeitung, Bd. 3, H. 11, 1. Juni 1906, str. 349 - 356, citirano str. 352.

18 Pokrovac, op. cit. u bilj. 5, str. 225.

19 Kako to pokazuje vodeći suvremeni pregled filozofije i teorije prava, Pattaro, E. (gen. ed.), A Treatise of Legal Philosophy and General Jurisprudence, 13 vol., Springer, Dordrecht, 2005. - 2016., osobito najopsežniji od prvih pet sistematskih volumena Sartor, G., Legal Reasoning: A Cognitive Approach to the Law, vol. 5, Springer, Dordrecht, 2005., 843 str.; i Feteris, E., Advancing Reason to Its Further Borders, u: Pattaro, E.; Roversi, C. (eds.), Legal Philosophy in the Twentieth Century: The Civil Law World, t. 2, Main Orientations and Topics, Springer, Dordrecht, 2016., str. 665 - 708.

20 Osobito: Esser, J., Grundsatz und Norm in der richterlichen Fortbildung des Privatrechts, Mohr, Tübingen, 1956.; Dworkin, R., Taking Rights Seriously, new impr. Duckworh, London, 1978. 
uvid navodi također na, s jedne strane, potrebu uključivanja nalaza i postupaka drugih znanosti, posebno društvenih, u pravno rasuđivanje i, s druge, upotrebu prava kao sredstva društvenog razvoja. Dakle, upućuje na mogućnost da pravo prestane biti vrijednosno neutralna struka i postane sredstvom političke skupine i čak političkog pokreta.

(2.2.3) Objava obrazloženja presuda omogućuje uočavanje, i priznanje, da je i sudstvo, po tome što i samo stvara pravo, politička grana vlasti. Dakako, mnogo je više vezano zakonom od ostalih grana. Političnost opravdava, a vezanost ograničava sudsku ocjenu zakonitosti upravne diskrecije i ustavnosti zakona, koje su ranije držane političkima i nepodsudnima. No objava presuda koja potiče političnost sudstva ne determinira sama po sebi njegovo kretanje. Može potaknuti neobuzdani finalizam, koji Pokrovac spominje sljedećim riječima:

Ako se objavljivanjem presuda povećava broj argumenata kojima se može obrazložiti odluka, te ako se time umanjuje predvidljivost odluke, onda se time povećava sudačka neovisnost, a vladavina prava kao vladavina zakona još više dovodi u pitanje. A to povećava i sudčevu slobodu..$^{21}$

No može potaknuti i traženje odgovora na sva pitanja o pravu u sve većem broju sve opsežnijih sudskih presuda, kao novom obliku formalizma. Iako je objava obrazloženih presuda nužan uvjet suvremenog kretanja prava, pretjerana bi bila tvrdnja da je ona sama uzrok tog kretanja. Pomoći može usporedba: Lutherov prijevod Biblije na pučki jezik i Gutenbergov tiskarski stroj bili su nužni uvjeti, ali ne i uzroci protestantizma.

(2.2.4) O objavi hrvatskih presuda dovoljno je ovdje istaknuti sljedeće: iole značajna objava izbora hrvatskih presuda nakon 1945. započeta je 1972. kao prvo zbirka sentenci (pravorijeka), a kasnije sažetaka presuda ${ }^{22}$; sudac Nikola Opatić stvorio je računalnu zbirku desetak tisuća presuda iz građanskog prava tada Općinskog suda u Zagrebu, daleko najvećega i najvažnijega u Hrvatskoj, koje su bile razmotrene od županijskog suda, a neke i od Vrhovnog suda; ta se zbirka dopunjuje te je danas dostupna putem portala Udruge hrvatskih sudaca ${ }^{23}$; sustavna objava presuda Vrhovnog suda RH počela je krajem 90-ih godina 20. stoljeća jer je bila uvjetom pristupanja Republike Hrvatske Europskoj uniji, a postupno je proširena izborom presuda nekih drugostupanjskih sudova te se sada objavljuje kao Sudska praksa VSRH-a. ${ }^{24}$ Sudski primijenjeno i/ili stvoreno pravo

21 Pokrovac, op. cit. u bilj. 5, str. 648 - 649 .

22 Naša zakonitost: časopis za pravnu teoriju i praksu; prilog: Pregled sudske prakse, 1972. - 1989.

23 http://www.uhs.hr/index.php/linkovi/supra

24 https://sudskapraksa.cspvsrh.hr/home 
moguće je izučavati - a pogotovo podučavati i naučiti - samo iz prvostupanjskih presuda jer samo one sadržavaju opis činjeničnog stanja i načina na koje je sud o njemu stekao spoznaju. Toj svrsi može poslužiti samo zbirka Općinskog suda u Zagrebu. Pritom povremeni uvid u presude sadržane u toj zbirci pokazuje da su one koje je izvorno izabrao i priredio njezin osnivač u prvih desetak godina postojanja opširnije od onih izabranih i priređenih posljednjih godina. Novije izabrane su uglavnom sažeci, i to takvi u kojima je, ako uopće, krajnje sažeto navedeno činjenično stanje. Tako je talijanski Kasacijski sud prvih nekoliko desetljeća nakon rata objavljivao svoje presude. Umjesto da objavi opis činjeničnog stanja, koji je od Kasacijskog suda ionako krajnje sažet, na mjestu opisa objavio je omissis. ${ }^{25}$ Takav postupak olakšava sudovima da se služe pravnim mjerilima kao naljepnicama koje mogu proizvoljno, jer i vlastite - ionako šture - razloge smiju uskratiti javnosti, lijepiti na pravno važne činjenice. Na taj način je rasuđivanje hrvatskih sudova stvorilo "zatvoreni sistem pojmova i stavova iz kojeg navodno rezultira svaka odluka" (supra 2.1). Uslijed smanjene dostupnosti svojega ionako oskudnog predmeta, od tog pravca ne mogu se znatno udaljiti hrvatske pravnoznanstvene discipline koje izučavaju pozitivno pravo.

(2.3). Kantorowicz utemeljuje svoje poimanje pravne znanosti (Jurisprudenz) u filozofiji Heinricha Rickerta, po kojoj se sve znanosti dijele po dva mjerila: prvo, materijalnom, tj. po tom "promatraju li svoj predmet načelno u odnosu na kulturne vrijednosti”, u prirodoznanstvo i kulturoznanstvo; drugo, formalnom, tj. po tom jesu li generalizirajuće ili individualizirajuće. ${ }^{26}$ Pokrovac sažima Kantorowiczevo poimanje iz $1925 .^{27}$, koje je i danas utjecajno, ovako:

pravoznanstvo se može pitati o smislu (Sinn), vrijednosti (Wert) i zbiljskosti (Wirklichkeit) prava te zato mora postupati $i$ konstruktivno i kritički i empirijski; drži li se neki od tih načina postupanja za jedini način postupanja, tad je riječ o odgovarajućem ograničenom dogmatizmu, racionalizmu ili historizmu. S obzirom na tri načina postupanja rezultiraju i tri različite discipline: opća nauka prava (Allgemeine Rechtslehre), filozofija prava i sociologija prava. Takva trodioba je po Kantorowiczu, rezultat sistematskog (generalizirajućeg ili tipologijskog) postupanja pravne znanosti; postupa li pravna znanost individualizirajuće (historijski) nadaje se za svaku od spomenutih disciplina odgovarajući pendant: za opću pravnu nauku pravna dogmatika ("»pravo«

25 Capeletti, M.; Merryman, J. H.; Perill, J. M., The Italian Legal System: An Introduction, Stranford University Press, Stanford CA, 1967., str. 245 - 246.

26 Pokrovac, op. cit. u bilj. 5, str. 133, bilj. 2, navodi da Kantorowicz upućuje na sljedeća djela Heinricha Rickerta: Die Grenzen der naturwissenschaftlichen Begriffsbildung, Mohr, Freiburg i. B., 1902.; Kulturwissenschaft und Naturwissenschaft, Mohr, Freiburg i. B., 1899.; Zur Lehre von der Definition, Wagner Druck, Freiburg i. B., 1888.

27 Kantorowicz, Staatsauffassungen, op. cit. u bilj. 1. 
pravoznanstvo"), za filozofiju prava politika prava, za sociologiju prava historija prava. Dakle, radi se o dvostrukoj trodiobi ili o šesterodiobi. ${ }^{28}$

\section{(3) Funkcije pravne znanosti}

(3.1) Uzme li se Kantorowiczeva šesterodioba u njezinu kontekstu, po njoj ne postoji šest odvojenih znanosti o pravu nego postoje funkcije - ali ne nužno njih šest - jedinstvene pravne znanosti.

(3.1.1) Podrobno, po Kantorowiczevoj šesterodiobi ne postoji šest znanosti koje su odvojene na taj način da svaka od njih ima svoje vlastite probleme i metode te tim metodama dobivene smislene spoznaje neovisne o spoznajama dobivenima metodama drugih znanosti o pravu; po toj diobi jedinstvena pravna znanost dijeli se u funkcije pravne znanosti, koje sve imaju zajedničke probleme, a rješavaju ih svaka pretežno jednom metodom, no spoznaje koje njom dobiva ovise o spoznajama dobivenima metodama nosivima za druge discipline, tj. funkcije pravne znanosti ili čak drugih znanosti.

(3.1.2) Kantorowiczevo uvrštavanje filozofije prava u funkcije pravne znanosti izgleda kao koncesija, prvo, u njegovo doba još uvijek gotovo neosporenom uvjerenju da postoji neiskustvena spoznaja i da je filozofija samostalna disciplina po tom što spoznaje neiskustveno; te, drugo, poimanju južnonjemačkog novokantovstva, kojemu pripada i Rickertovo učenje, da su sudovi o vrijednostima temeljni moralni sudovi, odnosno sudovi o tom kako ljudi treba da djeluju; treće, $u$ to vrijeme raširenom uvjerenju da su vrijednosti subjektivne, pa dakle ne mogu biti dio prava i predmet pravne znanosti, nego samo predmet filozofije - a to drugo ne može biti Kantorowiczevo stajalište.

(3.1.3) Kantorowiczev napor da pokaže važnost sociologije prava ne spominje da ona može biti važna za pravnu dogmatiku samo putem pravne politike - a potonju zanemaruje.

(3.1.4) Polazište je odredaba disciplina, metoda, predmeta i funkcija pravne znanosti dvojako. Prva je praksa u Hrvatskoj. Druga je teorija u njezinome kontinentalnoeuropskom, tj. romansko-germanskom (pretežno germanskom) okruženju, i to na zalazu moderne. ${ }^{29}$ Dakle, prije nekih pol stoljeća, kad je

28 Pokrovac, op. cit. u bilj. 5, str. 160 - 161.

29 Osobito: Jahr, G.; Maihofer, W. (Hrsg.), Rechtstheorie: Beiträge zur Grundlagendiskussion, Klostermann, Frankfurt a. M., 1970.; Albert, H. u. a. (Hrsg.), Rechtstheorie als Grundlagenwissenschaft der Rechtswissenschaft, Bertelsmann, Düsseldorf, 1972. = Jahrbuch der Rechtssoziologie und Rechtstheorie, Bd. 2, 1972. 
znanstveno djelovanje još slijedilo kanone, a nije, poput postmoderne religije, bilo složeno po ukusu svakoga pojedinoga koji se tako osjeća. S tog polazišta četiri su vrste ili discipline pravnih znanosti: dogmatika, historija, teorija i politika $(3.2-3.5)$.

\section{(3.2) Pravna dogmatika}

(3.2.1) Pravna dogmatika (njemački također Jurisprudenz ${ }^{30}$; hrvatski ponekad dogmatska jurisprudencija ${ }^{31}$ ) sistematizira i tumači pozitivno pravo $^{32}$ radi olakšavanja njegove primjene, osobito u sudovanju. ${ }^{33}$

(3.2.2) Naziv pravna znanost se u njemačkom (Rechtswissenschaft), a i u drugima kontinentalnoeuropskim jezicima pod utjecajem njemačkog prava, nerijetko upotrebljava kao istoznačnica izraza pravna dogmatika. ${ }^{34}$ Razlog je vjerojatno prihvat Savignyjeva poimanja pravne znanosti kao historijske i

30 Npr. Dreier, R., Zum Selbstverständnis der Jurisprudenz als Wissenschaft, 1971., u: Idem, Recht-Moral-Ideologie: Studien zur Rechtstheorie, Suhrkamp, Frankfurt a. M., 1981., str. 48 - 69. Jurisprudenz ima u njemačkom u pravilu isto značenje kao Rechtsdogmatik, nerijetko isto značenje i kao Rechtswissenschaft, koje je različito od značenja francuskog izraza jurisprudence, koji označava presude (sudsku praksu, judikaturu), osobito onu snage presedana, i od onoga engleskog jurisprudence, koji označava i presude i pravnu nauku u najširem smislu, od filozofijske do sociologijske.

31 Lanović, M., Uvod u pravne nauke, 2. izd., Državni tiskarski zavod, Zagreb, 1942., str. $28-30$.

32 Iako pravna dogmatika kao pravna znanost po definiciji pretpostavlja da je njezin glavni predmet istraživanja pozitivno pravo, značenje i podrijetlo izraza pozitivno pravo notorno su nejasni. Npr. Grawert, R., Recht positives; Rechtspositivismus, u: Historisches Wörterbuch der Philosophie (dalje u tekstu: HWP), Bd. 8, Schwabe, Basel, 1992., str. $234-242$.

33 Osobito: Aarnio, A., Denkweisen der Rechtswissenschaft, Springer, Wien, 1979., str. 34; Dreier, op. cit. u bilj. 30. Vidi Kantorowicz, op. cit. u bilj. 1; Herberger, M., Dogmatik: Zur Geschichte von Begriff und Methode in Medizin und Jurisprudenz, Klostermann, Frankfurt a. M., 1981.; Bumke, C., Rechtsdogmatik: Eine Disziplin und ihre Arbeitsweise. Zugleich eine Studie über das rechtsdogmatische Arbeiten Friedrich Karl von Savignys, Mohr, Tübingen, 2017.; Lanović, op. cit. u bilj. 31, str. 28 - 30.

34 Npr. Pawlowski, H.-M., Das Studium der Rechtswissenschaft, Mohr, Tübingen, 1969., str. 18 i dr.; Adomeit, K., Rechtswissenschaft, u: Görlitz, A. (Hrsg.), Handlexikon zur Rechtswissenschaft, Rowohlt, Reinbek bei Hamburg, 1972., str. 369; Rüthers, B., Rechtstheorie: Begriff, Geltung und Anwendung des Rechts, Beck, München, 1999., str. $159-166$. 
filozofijske znanosti $\mathrm{i}^{35}$ koja ujedinjuje spoznaje dobivene istraživanjem pravnog jezika, pravne povijesti i pravnog sistema. ${ }^{36}$ Stoga je i po današnjem poimanju prva integralna pravna znanost, koja izučava pozitivno pravo i izvanpozitivne vrijednosti u njihovu društvenom kontekstu. ${ }^{37}$

(3.2.3) Ako se pozitivno pravo shvati kao dio svakodnevnog jezika zaokupljen pravom, pravna dogmatika je po nakani metajezik pozitivnog prava (ne i po izvedbi jer u najmanju ruku do sada nije uspjelo, a po filozofiji svakodnevnog jezika nije ni moguće, izgraditi umjetni jezik potpuno neovisan o svakodnevnom $\left.^{38}\right)$.

(3.2.4) Pravna dogmatika je ponajprije opravdavajuća disciplina. Poput drugih praktičnih disciplina (osobito normativne etike, politike ili ekonomije) ocjenjuje određena djelovanja, uključujući pravnostvaralačka (pravne poslove, presude, zakone itd.) kao pravna ili protupravna. No, za razliku od drugih praktičnih disciplina, ocjenjuje djelovanja na temelju izvora prava, tj. u prvom redu pozitivnih (i to u uskom smislu ljudski ili, štoviše, ljudskom voljom stvorenih ${ }^{39}$ ) mjerila djelovanja (pravila/normi, vrijednosti i načela, no također njihovih skupova kao što su pravne ustanove, grane, sistemi itd.). Trajno je otvoreno pitanje u kojoj su mjeri izvori pozitivnog prava odvojivi od možebitnih iznadpozitivnih mjerila djelovanja (prirodnog ili umnog prava; drukčije: apsolutnog morala). Ovisno o odgovoru na to pitanje pravna dogmatika se drži više ili manje odvojivom od drugih praktičkih disciplina, tj. etike i politike.

(3.2.5) Pravna dogmatika je i objašnjavajuća disciplina. Poput drugih društvenoznanstvenih (npr. ekonomskih) i humanističkih (npr. filologijskih) te prirodoslovnih disciplina (osobito medicinskih i tehničkih) uzročno objašnjava određena djelovanja, u pravilu njihovim djelatnim uzrocima (causae efficientes). No poput historije, a različito od većine drugih znanstvenih disciplina, zaokupljena je ponajprije pojedinačnim uzrocima i uzročno-posljedičnim vezama

35 Npr. Savigny, F. C. v., Vorlesungen ueber juristische Methodologie 1802-1842, hrsg. u. eing. v. Mazzacame, A., Klostermann, Frankfurt a. M., 2004., str. 91 - 92.

36 Ibid., str. 97 - 103, 119 - 129. Nörr, D., Savignys philosophische Lehrjahre: Ein Versuch, Klostermann, Frankfurt a. M., 1994., str. 243 i d., 250 i d. Meder, S., Missverstehen und Verstehen: Savignys Grundlegung der juristischen Hermeneutik, Mohr, Tübingen, 2004., str. 170 i d.

37 Tako Visković, N., Pojam prava: prilog integralnoj teoriji prava, 2. izd., Logos, Split, 1983., str. 34.

38 Npr. Lyons, J., Semantics, vol. 1, Cambridge University Press, Cambridge, UK, 1979., str. 12 .

39 Akvinski, T., Suma protiv pogana, Kršćanska sadašnjost, Zagreb, 1994., lb. 3, cap. 125, spominje "lex divinitus posita”, tj. božansko pozitivno pravo. 
(pitanjima poput "Je li N. N. umro od ranije bolesti ili kasnije rane?", "Zašto je zadruga završila poslovnu godinu s gubitkom?”). Njih pak objašnjava najčešće na temelju svakodnevnog iskustva i osebujnih pravničkih teorija uzročnosti (osobito adekvacijske ${ }^{40}$ ). Ne objašnjava ih na temelju obuhvatnih društvenih zakona ili zakonitosti (npr. da se u seoskim zajednicama nakon dobrog uroda sklapa više brakova), vjerojatno ni u slučajevima u kojima preuzima objašnjenja što ih daju vještaci iz drugih znanosti i struka. Pritom su predmet pravnodogmatskih objašnjenja kako predmeti koje pravo uređuje (npr. tjelesna povreda, predaja stvari) tako i samo pravo, osobito vjerojatnost da postojeća sudska praksa utječe na buduću ili da određena djelovanja i njihova opravdanja stvore pravilo običajnog prava. ${ }^{41}$ Upravo zbog potonjeg razloga također je trajno otvoreno pitanje u kojoj su mjeri izvori pozitivnog prava odvojivi od izvanpozitivnih mjerila djelovanja (osobito pozitivnog, tj. konvencionalnog morala) i, još više, od izvanpravnih djelovanja i njihovih učinaka (npr. ekonomske recesije). Ovisno o odgovoru na to pitanje pravna dogmatika drži se više ili manje odvojivom od, s jedne strane, opće historije i drugih posebnih historija (npr. politike, religije) i, s druge, teorijskih društvenih znanosti (npr. sociologijskih, ekonomskih), koje objašnjavanju svoje predmete na temelju obuhvatnih zakona.

(3.2.6) Pravna dogmatika u pravilu nije sveobuhvatna disciplina u tom smislu da izučava cijelo pozitivno pravo, npr. hrvatsko ili njemačko, nekmoli više pozitivnih prava ili pravo naprosto, nego izučava dio pravnog sistema, npr. hrvatsko građansko ili njemačko kazneno pravo; iznimka je dogmatika međunarodnog prava $^{42}$; no čak je potonja ranije shvaćana i izvođena kao disciplina vanjskoga državnog prava, tj. onog dijela državnog prava koji uređuje odnose države $s$ drugim državama. ${ }^{43}$ Tako su u Republici Hrvatskoj kao grane polja pravo unutar područja društvenih znanosti priznate sljedeće discipline koje su u hrvatskoj pravnoznanstvenoj praksi izvođene pretežno kao pravnodogmatske: europsko javno pravo; europsko privatno pravo; financijsko pravo; kazneno pravo, kazneno procesno pravo, kriminologija i viktimologija; građansko pravo i građansko

40 Npr. Koriath, H., Kausalität und objektive Zurechnung, Nomos, Baden-Baden, 2007., str. 37 - 71. Drukčije, Martinović, I., Problem uzročnosti u kaznenom pravu, Hrvatski ljetopis za kazneno pravo i praksu, vol. 19, br. 1, 2012., str. 75 - 104.

${ }^{41}$ Npr. D’Amato, A. A., The Concept of Custom in International Law, Cornell University Press, Ithaca NY, 1971.

42 Adomeit, op. cit. u bilj. 34, str. 369.

43 Tako i prvo stoljeće i pol Pravnog fakulteta u Zagrebu. Bakotić, B., Katedra za međunarodno pravo - povijesna skica, u: Pavić, Ž. (ur.), Pravni fakultet u Zagrebu 17761996, knj. II., Prilozi za povijest katedri i biblioteke, sv. 1., Pravni fakultet, Zagreb, 1996., str. $325-328$. 
procesno pravo; međunarodno pravo; međunarodno privatno pravo; obiteljsko pravo; rimsko pravo; pomorsko i općeprometno pravo; radno i socijalno pravo; trgovačko pravo i pravo društava; upravno pravo i uprava; ustavno pravo. ${ }^{44}$ Uslijed toga što pravna dogmatika izučava samo dio pravnog sistema, nedostatna je u dva pogleda. Prvo, po predmetu, jer svojemu predmetu - npr. hrvatskome građanskom pravu - ne može odrediti cjelinu kojoj pripada, a to je hrvatsko pravo, odnosno hrvatski pravni sistem. To je moguće naslutiti iz činjenice da pravna dogmatika po pretežnom stajalištu ne uključuje izbor prava. ${ }^{45}$ Ex hypothesi ne uključuje ga zbog toga što je u moderno vrijeme, od XI. stoljeća naovamo, pravna dogmatika nastala kao ponajprije dogmatika privatnog prava, i to na pretpostavci da je Justinijanova kodifikacija rimskog prava ne samo jus scriptum nego ratio scripta, koji ne vrijedi samo ratione imperii nego imperio ratione. ${ }^{46}$ Tako je vjera u Justinijanovu kodifikaciju postala obrascem kasnije vjere u jedinstvo pravnog poretka, koje je zajamčeno njegovim izvorom. ${ }^{47}$ Upravo neupitni izvor prava omogućio je dogmatici da objašnjava svoje predmete i kao da je teorijska disciplina ${ }^{48}$ Drugo, pravna dogmatika je nedostatna po pojmovima jer pojmove o svojemu predmetu ne može odrediti neovisno o pojmovima o predmetima drugih pravnih dogmatika i, još više, neovisno o pojmovima prava u cjelini, kao što su to pojmovi pravnog pravila, pravne vrijednosti, pravnog subjekta, pravne radnje, krivnje, izvora prava, pravnog sistema, itd., koji su po tom - u pravilu temeljni pravni pojmovi, koji su istraživi pravnom teorijom.

(3.2.7) Iako sličnost naziva i nekih funkcija teologijske i pravne dogmatike navodi na zaključak da je potonja stvorena po uzoru na prvu, pravnici su pojam dogmatike preuzeli iz medicine, u kojoj medicinska dogmatika označava ispravno služenje dogmama u smislu općih sudova koji su stvoreni poopćavanjem iskustava i koji su samo vjerojatno istiniti, pa stoga zahtijevaju stalno kritičko

44 Pravilnik o znanstvenim i umjetničkim područjima, poljima i granama, Narodne novine, br. 118/2009 118/2009, 82/2012, 32/2013 i 34/2016, čl. 4., t. 5.02.

45 Npr. Aarnio, op. cit. u bilj. 33, Dreier, op. cit. u bilj. 30 i Bumke, op. cit. u bilj. 33 ne određuju da je iznalaženje i priznavanje izvora prava zadatak pravne dogmatike koji je jednako važan kao tumačenje i sistematizacija prava.

46 Koschaker, P., Europa und das Römische Recht, 2. Aufl., Beck, München, 1953., str. $108-109$.

47 Vidi Engisch, K., Die Einheit der Rechtsordnung, Carl Winters, Heidelberg, 1935.; Baldus, M., Die Einheit der Rechtsordnung: Die Bedeutung einer juristischen Formel in Rechtstheorie, Zivil- und Strafrechtswissenschaft im 19. und 20. Jahrhunderts, Duncker \& Humblot, Berlin, 1995.; Felix, D., Einheit der Rechtsordnung: Zur verfassungsrechtlichen Relevanz einer juristischen Argumentationsfigur, Mohr, Tübingen, 1998.

Dreier, op. cit. u bilj. 30. 
preispitivanje na temelju novih iskustava. Takvim su dogmatskim disciplinama još krajem XIX. stoljeća bile ne samo medicinska i pravna dogmatika nego i tehničke discipline. ${ }^{49}$ Pravna znanost, a ponajprije pravna dogmatika, bila je utjecana i na druge načine od prirodnih znanosti i matematike. ${ }^{50}$ Tako je pravna dogmatika od samih početaka u značajnoj mjeri naturalistička ili, točnije, dijelom naturalizirana disciplina.

(3.2.8) Pravna doktrina, protivno tome što se tvrdi čak u utjecajnim publikacijama $^{51}$, nije zajednički nazivnik pravne dogmatike i toga što pišu angloamerički sveučilišni nastavnici prava. To zbog toga što funkciju koju u europskim pravima imaju profesori prava u angloameričkom svijetu otpravljaju suci. ${ }^{52}$ Stoga su temeljni pojmovi pravne dogmatike i angloameričke pravne doktrine različiti. Tako pojmovi pravnog subjekta, pravnog objekta i pravnog organa, koji su ključni u prvoj, u drugoj se ni ne rabe. Stoga su i pojmovi koje engleski student prava uči po europeiziranim udžbenicima (a američki ih ni nije nikada učio) engleskim solicitors nepotrebni i nerazumljivi. ${ }^{53}$

\section{(3.3) Pravna historija}

(3.3.1) Pravna historija, čiji je predmet pravna povijest, poput opće historije ili druge posebne historije, npr. gospodarske, istražuje u prvom redu pojedinačne uzročno-posljedične veze između pravnih pojava ili između njih i nepravnih pojava. ${ }^{54}$

49 Herberger, op. cit. u bilj. 33. Vidi ukratko, Idem, Rechtsdogmatik, u: HWP, Bd. 8, Schwabe, Basel, str. $266-71$.

50 Stephanitz, D. v., Exakte Wissenschaften und Recht. Der Einfluss von Naturwissenschaft und Mathematik auf Rechtsdenken und Rechtswissenschaft in zweieinhalb Jahrtausenden. Ein historischer Grundriss, Walter de Gruyter, Berlin, 1970.

51 Peczenik, A., Scientia Juris: Legal Doctrine as Knowledge of Law and as a Source of Law, vol. 4, u: Pattaro (gen. ed.), op. cit. bilj. 19, Springer, Dordrecht, 2007., str. 1 - 2 i d.

52 Stith, R., Can Practice Do Without Theory? Differing Answers in Western Legal Education, Archiv für Rechts- und Sozialphilosophie, Bd. 80, H. 3, 1994., str. 426 - 435. Vidi povijesne uzroke Caenegem, R. C., Judges, Legislators, and Professors: Chapters in European Legal History, Cambridge University Press, Cambridge, UK, 1967.

53 Nicholas, B., Le language des biens dans le common law, Archives de philosophie du droit, vol. 24, Les biens et les choses en droit, Sirey, Paris, 1979., str. 55 - 63.

54 Vidi Wieacker, F., Privatrechtsgeschichte der Neuzeit, 2. Aufl., Vandenhoek \& Ruprecht, Göttingen, 1967., str. 17; Kantorowicz, Rechtswissenschaft, op. cit. u bilj. 1, str. 23; Pokrovac, op. cit. u bilj. 5, str. 113 - 118; Lanović, op. cit. u bilj. 31, str. 26 - 27, t. 3. 
(3.3.2) Po autoritativnom stajalištu, historija prava je duhovna, tj. humanistička znanost. ${ }^{55}$ Razlozi zbog kojih je u Republici Hrvatskoj priznata kao grana polja prava društvenih znanosti ${ }^{56}$ na prvi su pogled nasljeđe (dva - od ukupno četiri - ispita zagrebačkog studija prava u desetljeću prije II. svjetskog rata bila su uglavnom iz historije prava ${ }^{57}$ ), nastavne pogodnosti (pravnim fakultetima pogodnije je da im nastavu historije prava drže vlastiti nastavnici a ne vanjski suradnici) i nerazumljivost pravne povijesti (slično kao i npr. glazbene) općim i posebnim historičarima u matičnim fakultetima humanističkih znanosti. Barem su tri jaka razloga zbog kojih je historija prava neizostavni sastojak pravnih znanosti. Prvi je taj da je historijska metoda nosiva i za pravne dogmatike (supra 3.2.5). Stoga je historija prava kako je ona razvijena u Pravnom fakultetu u Zagrebu teško zamjenjiv pristup pojedinim izvorima prava i njihovim sistemima. Drugi je razlog taj da je predmete historije prava, npr. sastavne dijelove jugoslavenskog prava 1945. - 1990., moguće prepoznati i odrediti samo pravnoteorijski i pravnodogmatski. Treći je taj da je značajan dio pravne povijesti objašnjiv ponajprije unutrašnjim pravnim uzrocima, tj. mogućnošću samih pravnih mjerila da - zahvaljujući svojoj racionalnosti i pravednosti - budu uzrocima takvih novih mjerila. ${ }^{58}$ A ti unutrašnji pravni uzroci nisu razumljivi bez pravnodogmatskih opravdanja.

(3.3.3) Historija prava kao moderna znanost formirana je u historijskoj pravnoj školi početkom 19. stoljeća ${ }^{59}$, i to kao teorija razvoja prava, iz koje se kasnije razvila $u$ disciplinu pod nazivom pravna teorija. ${ }^{60}$

55 Simon, D., Rechtsgeschichte, u: HzR, str. 314 - 318, na str. 314. Simon je bio profesor građanskog prava i rimskog prava na Goethe Sveučilištu (1968. - 1991.) i direktor Max Planck Instituta za europsku pravnu povijest (1980. - 2003.) u Frankfurtu na Majni.

56 Pravilnik, op. cit. u bilj. 44, čl. 4., t. 5.02.08.

57 Sirotković, H., Organizacija i djelovanje Fakulteta od 1918. do danas, u: Filipović, N.; Sokol, S. (ur.), Pravni fakultet u Zagrebu 1945-1980, Pravni fakultet, Zagreb, 1980., str. $50-51$.

58 Vidi osobito Watson, A., The Evolution of Law, The Johns Hopkins University Press, Baltimore, 1985., ch. III. "The Cause of the Reception of Roman Law", str. 66 - 97.

59 Wieacker, op. cit. u bilj. 54, str. 348 i d.

60 Broeckmöller, A., Die Enststehung der Rechtstheorie im 19. Jahrhundert in Deutschland, Nomos, Baden-Baden, 1997., str 1 - 82. Ukratko Hoecke, M. v., What is Legal Theory, Acco, Leuven, 1995., str. 27 - 38. 


\section{(3.4) Pravna teorija}

(3.4.l) Pravna teorija po nakani je opća pravna znanost, a istražuje temeljne pravne pojmove kao što su pojmovi pravnog subjekta, pravnog objekta, subjektivnog prava, izvora prava i tumačenja prava te, najvažnije, pravnog sistema i odnosa među pravnim sistemima ${ }^{61}$ te se time širi i u istraživanju međuutjecaja prava i njegove okoline.

(3.4.2) Analitička teorija prava, koja je polazište teorije prava, po nakani je (ali ne po izvedbi, iz razloga supra 3.2.3) metadisciplina: po onom istom obrascu po kojemu je pravna dogmatika metapravo, teorija prava je metadogmatika, koja objašnjava logički i jezični sastav pravne dogmatike, osobito temeljne pravne pojmove kao što su pojmovi pravnog subjekta, pravnog objekta, subjektivnog prava, izvora prava i tumačenja prava te, najvažnije, pojam pravnog sistema i odnose među pravnim sistemima. ${ }^{62}$

(3.4.3) Teorijskopravno objašnjenje je, poput pravnodogmatskoga, barem na prvi pogled, propisno, i to po predmetu (koji čine pravna mjerila, tj. propisi, osobito pravila, vrijednosti i načela), metodi (propise ocjenjuje kao sukladne ili protivne drugim propisima) i, ponekad, funkciji (stvara propise). ${ }^{63}$ No, ponekad je propisivanje teško razlučivo od opisivanja. ${ }^{64}$ Npr. kad teorija prava određuje pravni subjekt kao točku uračunavanja koja je ustanovljena određenim subjektivnim pravima, posebice pravima na postojanje i saobraćaj, teško je ocijeniti je li ta

${ }^{61}$ Npr. ibid., str. 43 - 48. Vidi izvore tog shvaćanja sustavno izložene u: Priester, J.-M., Rechtstheorie als analytische Wissenschaftstheorie, $\mathrm{u}$ : Jahr, Rechtstheorie, op. cit. $\mathrm{u}$ bilj. 29, str. 13 - 61; Jahr, G., Zum Verhältnis von Rechtstheorie und Rechtsdogmatik, u: Jahr, Rechtstheorie, op. cit. u bilj. 29, str. 303 - 311; Maihofer, W., Rechtstheorie als Basisdisziplin der Jurisprudenz, u: Albert, op. cit. u bilj. 29, str. 51 - 78, koji, međutim, priznaje da unutar teorije prava postoji također kritičko usmjerenje kao alternativa analitičkome. O drugima važnijim značenjima izraza pravna teorija, odnosno smjerovima te discipline, osobito Dubischar, R., Einführung in die Rechtstheorie, Wissenschaftliche Buchgesellschaft, Darmstadt, 1983.

62 Npr. Tucak, I., Hohfeldova analitička teorija prava, Pravni fakultet Sveučilišta J. J. Strossmayer, Osijek, 2016., str. 255 - 322.

63 Bobbio, N., 'Sein' and 'Sollen' in Legal Science, Archiv für Rechts- und Sozialphilosophie, Beiheft N. F., 6, 1971., str. 7 - 32; prijevod Bitak $i$ trebanje u pravnoj znanosti, u: Idem, Eseji iz teorije prava, prijevod, Logos, Split, 1988., str. 31 - 50. Kritika Padjen, I., Metodologija pravne znanosti: pravo i susjedne discipline, Pravni fakultet Sveučilišta u Rijeci, Rijeka, 2015., str. 87 - 116.

64 Vidi osobito Fuller, L. L., Human Purpose and Natural Law, Natural Law Forum, vol. 3, 1956., str. 68 - 76, i raspravu s E. Nagelom u istom časopisu, pretiskano u: Finnis, J. (ed.), Natural Law, Dartmouth, Aldershot, 1991., str. 3 - 60. 
odredba propis (stipulativna definicija) ili opis uvjeta koji su nužni za postojanje pravnog subjekta, a informirani su iskustvom prava.

(3.4.4) Teorija prava ima i vlastiti predmet, koji dogmatske pravne discipline $\mathrm{u}$ pravilu nemaju, a to je pravni sistem ${ }^{65}$, osobito dioba sistema, izvori pravnog sistema i njihovo tumačenje. Prvenstveni je predmet teorije prava konkretni pravni sistem, npr. hrvatski ili njemački ili međunarodni, u pravilu onaj s kojim su najtješnje povezani proizvođači (autori) i potrošači (čitatelji) pojedinoga teorijskopravnog djela, osobito udžbenika. ${ }^{66}$ Ako se teorija shvaća kao apstrakcija, konkretni pravni sistem kao predmet teorije prava doima se neteorijskim. Međutim, ipak je teorijski, i to u smislu moderne teorije (čiji su obrazac matematika i prirodne znanosti), u dva pogleda. S jedne strane, moderni pojmovi pravnog sistema nastali su u 17. i 18. stoljeću primjenom matematike, dijelom kao aksiomatskodeduktivni sistemi ${ }^{67}$; stoga je konkretni pravni sistem u krajnjoj crti pretpostavka važenja određenih pravnih mjerila za koja se drži da udovoljavaju - u pravilu izvanpozitivnim - mjerilima važenja, osobito prirodnom zakonu i društvenoj učinkovitosti, no čije udovoljavanje tim mjerilima je, po njihovoj naravi, mnogo teže dokazati nego udovoljavanje pozitivnopravnih pravila, vrijednosti i načela pozitivnopravnim mjerilima važenja koja sadržava sam pravni sistem. S druge, shvaćanje prava kao jedinstva općih/apstraktnih i pojedinačnih/konkretnih mjerila djelovanja ima, doduše, korijen u praktičkoj filozofiji, koja je usredotočena na djelovanje $\mathrm{e}^{68}$, no bliska je i induktivnom zaključivanju, karakterističnom za prirodne znanosti ${ }^{69}$, tako da je teško ocijeniti slijedi li induktivno pravno rasuđivanje, koje počinje od pojedinačnog djelovanja i nastavlja zaključivanjem po sličnosti dotle dok ne ustanovi opću praksu, više antičku praktičku filozofiju nego modernu prirodnu znanost. ${ }^{70}$ Stoga teorijskopravno djelo može, u pravilu, tek nakon što je uspješno odredilo svoj središ-

65 Osobito Raz, J., The Concept of a Legal System, Oxford University Press, Oxford, 1970., str. 3, pozivom na: Kelsen, H., General Theory of Law and State, tr., Russell \& Russell, New York, 1961., str. 3.

66 Perić, B., Struktura prava, 1. dio, 6. izd., Sveučilišna naklada Liber, Zagreb, 1978., "Predgovor" 1. izd., 1964., str. V - VI.

67 Björne, L., Deutsche Rechtssysteme im 18. und 19. Jahrhundert, Verlag Rolf Gremer, Ebelsbach, 1984., str. 15. Vidi i Stephanitz, op. cit. u bilj. 50, str. 120 - 134.

68 Akvinski, T., Summa Theologica, Ia2ae, u: Idem, Izbor iz djela, prij. 2. sv., Naprijed, Zagreb, 1990., pitanje 90, članak 1, odgovor na 2. razlog.

69 Osobito Mill, J. S., A System of Logic, $8^{\text {th }}$ ed., Harper \& Brothers, New York, 1882. Book III, str. 348 - 782; http://www.gutenberg.org/license. Ukratko Petrović, G., Logika, 11. izd., Školska knjiga, Zagreb, 1977., dio II.II., str. 149 - 169.

70 Primjer je Schwarzenberger, G., The Inductive Approach to International Law, Stevens \& Sons, London, 1965., osobito str. $37-42$. 
nji predmet, tj. svoj pravni sistem, biti donekle uspješno u određivanju drugih pravnih sistema, s tim što će biti to manje uspješno što su drugi pravni sistemi različitiji od glavnog predmeta. Zbog toga je i teorijskopravni pojam pravnog sistema, u onoj mjeri u kojoj je teorijski (tj. konstruiran tako kao da su pravna mjerila što čine sistem izvedena iz nekoliko postulata, aksioma i definicija, no stalno dovođena u vezu s pozitivnima $\mathrm{i} / \mathrm{ili}$ povijesnima $\mathrm{i} / \mathrm{ili}$ iskustvenima pravnim mjerilima), takoreći prirodno pojam konkretnoga pravnog sistema koji je primjenjiv i na nekoliko njemu sličnih. Dakle, teorijskopravni pojam pravnog sistema nije praktičkofilozofijski pojam pravnog sistema (tj. konstruiran tako kao da su pravna mjerila sistema apstrakcija prava različitih povijesnih zajednica i, štoviše, stalno dovođena u vezu s drugim apstrakcijama, kao što su to dobro i istina), koji je takoreći prirodno pojam prava naprosto pa stoga teško primjenjiv na bilo koji skup iskustvenih pravnih mjerila.

(3.4.5) Razvijena teorija prava sadržava i spoznaje važne za izučavanje transsistemskih pravnih problema, i to odnose pravnog sistema (npr. hrvatskog), s jedne strane, s drugim pravnim sistemima (npr. njemačkim, Europske unije) i, s druge, sa srodnim predmetima kao što su to osobito moral i politika (iako po nakani više s povijesnim i/ili pozitivnim i/ili iskustvenim moralom konkretne zajednice ili konkretnih zajednica nego s filozofijski pojmljenim moralom). U mjeri u kojoj je teorija prava zaokupljena odnosima među pravnim sistemima preklapa se također $\mathrm{s}$ disciplinama poredbenog prava, internacionalnog prava i internacionalnoga privatnog prava. U mjeri u kojoj je teorija prava zaokupljena odnosima s predmetima srodnima pravu teorija prava je teško odvojiva od, s jedne strane, historije prava i društvenih znanosti o pravu (politologijskih, sociologijskih, ekonomskih itd.) i, s druge, filozofije (prava, morala, politike itd.). Nerijetko se razvija u integralnu teoriju prava ${ }^{71}$ i spaja se s integralnom pravnom znanosti (supra 3.2.2, infra 3.5.3).

(3.4.6) Teorija prava nastaje na prijelazu u XIX. stoljeće kao disciplina koja istražuje pozitivno pravo i po tom različita od filozofije prava, koja je tada zaokupljena prirodnim i/ili umnim pravom, tj. pravom kao idealno postojećim i/ili važećim predmetom ${ }^{72}$ (supra 3.3.3). Teorija prava je usporediva vjerojatno prije sa sociologijskom teorijom nego s npr. sociologijom prava ili sociologijom politike, pogotovo ako se drži da su one, toliko-koliko su uopće svedive na zajednički nazivnik, objedinjene socijalnom teorijom. ${ }^{73}$

71 Npr. Visković, op. cit. u bilj. 37.

72 Vidi o kontinuumu znanstvene misli od metafizike do empirije u: Alexander, J. C., Theoretical Logic in Sociology, vol. 1, University of California Press, Berkeley, CA, 1982., str. $2-4$.

73 U smislu npr. Turner, B. S. (ed.), Blackwell Companion to Social Theory, Blackwell, Oxford, 1996.; Ritzer, G.; Smart, B. (eds.), Handbook of Social Theory, SAGE, London, 2003. 


\section{(3.5) Pravna politika}

(3.5.1) Pravna politika je istraživanje de lege ferenda (o pravu koje treba stvoriti), tj. predlaganje pravnih ciljeva i pravnih sredstava rješavanja društvenih problema. Odnedavno je oživio interes pravnika za zakonodavstvo, koje je, međutim, samo dio stvaranja prava ${ }^{74}$ (usp. supra 0.2 ).

(3.5.2) Policy oriented jurisprudence najobuhvatniji je i najrazrađeniji okvir pravne politike. ${ }^{75}$ Prilagođena je kao pravnopolitička analiza (dalje u tekstu: PPA) romansko-germanskom pravnom nasljeđu, pa tako i drugim funkcijama pravne znanosti (supra 3.2 - 3.4) $\cdot{ }^{76}$ Prije izvedbe istraživanja (infra B) određuje njegove sastojke (infra A).

(AA) Ishodište je PPA-a, koje određuje njegov tok u cjelini, identifikacija u smislu prepoznavanja i priznanja - praktičnog problema istraživanja. To je stanje društvenih odnosa (političkih, ekonomskih, zdravstvenih itd.) koje ne zadovoljava - npr. odluka Arbitražnog tribunala o hrvatsko-slovenskoj granici na moru (dalje u tekstu: OAT); javna upotreba pozdrava "Za dom spremni" (dalje u tekstu: ZDS) - a moglo bi biti unaprijeđeno drukčijim pravnim uređenjem. Teorijski problem istraživanja je nezadovoljavajuće stanje spoznaja, ponajprije znanstvenih, praktičnog problema te možebitnih uvjeta, ciljeva i sredstava njegova rješavanja. Tako već odredba praktičnog problema zahtijeva pregled i ocjenu postojeće znanstvene literature o problemu i njegovu rješavanju.

(AB) Identifikacija praktičnog problema neizbježno pretpostavlja, ali bez podrobnosti, dvoje. Prvo, konkretne ciljeve istraživanja. Konkretni cilj je stanje društvenih odnosa koje je zadovoljavajuće ili je barem manje nezadovoljavajuće od problematičnoga. Konkretni cilj pretpostavlja apstraktni cilj, tj. vrijednost, kao što je to npr. državna cjelovitost ili internacionalni poredak (važni za OAT) te sloboda izražavanja ili ustavni poredak (važni za ZDS). Drugo, identifikacija pretpostavlja sredstva istraživanja. To su pretpostavke (osobito teorije) i/ili načini

74 Npr. Flores, B., Legisprudence: The Problems and Limits of Legislation (21 Aug. 2018); https://www.researchgate.net/publication/316536515_Legisprudence_the_Forms_ and_Limits_of_Legislation (29. travnja 2019.).

75 Lasswell, H. D.; McDougal, M. S., Jurisprudence for a Free Society: Studies in Law, Science and Policy, 2 vols., Kluwer Law International, Alphen aan den Rijn, 1992., osobito uvod str. 3 - 38. Popis McDougalovih radova, uključujući one u suautorstvu s Lasswellom i njihovim brojnim suradnicima poznatima kao New Haven škola internacionalnog prava u: Myres Smith McDougal: Appreciations of an Extraordinary Man, Yale Law School, New Haven, CT, 1999., str. 128 - 140.

76 Padjen, op. cit. u bilj. 63, gl. 2.5.3 "Istraživanja de lege ferenda: Upotreba Lasswellove i McDougalove političkopravne analize”, str. 165 - 178; također radovi u bilj. 79. 
(metode) stjecanja znanja koje, s jedne strane, omogućuju stvaranje prava čija primjena će vjerojatno pretvoriti nezadovoljavajuće društvene odnose u manje nezadovoljavajuće; a, s druge, neizbježno sadržavaju vrijednosti što makar šutke usmjeravaju spoznaju. Upravo zbog toga PPA postavlja istraživaču tri zahtjeva.

(ABA) Postulacija sistemskih vrijednosti istraživanja i njihovih međusobnih odnosa, kao što su to one supra AB ili sl. PPA zahtijeva da istraživač sistemske vrijednosti postulira, a ne dokazuje. To zato da se izbjegne beskrajno izvođenje vrijednosti iz njima viših vrijednosti karakteristično za filozofiju. Postulacija nije proizvoljna nego pretpostavlja, zahtijeva ili uključuje, među ostalim, sljedeće: eksplikaciju vrijednosnih pretpostavki; ograničenje izbora pravnih sistema te ustavnih strogih načela iz mnoštva odluka koje bi mogle imati tu važnost (infra BA); granice mogućih odnosa između sistemskih vrijednosti i svih drugih sastojaka istraživanja, tj. pravnih odluka (infra BA - BF).

(ABB) Izbor i dogradnja teorijskog i/ili metodologijskog okvira istraživanja, koji uključuje prihvat ili izgradnju temeljnih teorija (npr. integralnu teoriju prava, historijski institucionalizam itsl.), pojma prava i drugih temeljnih pravnih pojmova (npr. prometa), nedokazivih pretpostavki istraživanja i prešutne vrijednosti okvira.

(ABC) Konkretizacija okvira i vrijednosti u odredbi konkretnih predmeta, hipoteza i metoda istraživanja.

(B) PPA može izučavati rješavanje praktičnog problema u jednome pravnom sistemu, npr. internacionalnom, koje se ovdje prikazuje, ili u dva ili više pravnih sistema, npr. internacionalnom i hrvatskom. Izvedba ima sljedeće glavne sastojke:

(BA) Izbor ustavnih ili strogih (kogentnih) načela koja su najviše u skladu sa sistemskim vrijednostima (supra ABA). Npr. u rješavanju OAT-a dobre vjere ili nadležnosti arbitraže da odlučuje o vlastitoj nadležnosti; u rješavanju ZDS-a zabrane govora mržnje ili poštovanja Domovinskog rata.

(BB) Opis interesa koje sudionici (strane u sporu, treći) nastoje ostvariti rješavanjem problema.

(BC) Opis dosadašnjih pravnih odluka o problemu i njihova ocjena kao infra, contra ili praeter ustavnih ili strogih načela (supra BA) i sistemskih vrijednosti (supra $\mathrm{ABA}$ ) te interesa sudionika (supra $\mathrm{BB}$ ).

(BD) Opis uvjeta, tj. čimbenika i/ili uzroka, institucionalnih i izvaninstitucionalnih, koji su utjecali na odluke (supra BC).

(BE) Polazeći od uvjeta (supra BD) i važnosti za sistemske vrijednosti (supra $\mathrm{ABA}$ ) predviđanje budućih uvjeta i vjerojatnih budućih odluka ako se ne stvore alternativne (infra $\mathrm{BF}$ ) te ocjena budućih odluka kao infra, contra ili praeter ustavnih ili strogih načela (supra BA) i sistemskih vrijednosti (supra ABA) te interesa sudionika (supra BB). 
(BF) Iznalaženje alternativnih pravnih odluka koje su više od vjerojatnih budućih pravnih odluka infra ustavnih ili strogih načela (supra BA) i sistemskih vrijednosti (supra ABA) te procjena utjecaja alternativnih odluka na interese sudionika (supra BB).

(3.5.3) PPA obavlja sve funkcije pravne znanosti, a može imati i one drugih društvenih znanosti. Podrobno: funkcija ABB je teorijska u smislu supra 3.4; funkcije BA + BC su dogmatske u smislu supra 3.2; funkcije BB + BD su historijske u smislu supra 3.3, a proširive su psihologijom, sociologijom, ekonomskom analizom prava i dr.; funkcije BE + BF su političke u užem smislu, povezive su i s dogmatskima i historijskima, a neizbježno uključuju - kao i svako istraživanje de lege ferenda - stvaralačku maštu koja je bliža umijeću nego znanosti.

(3.5.4) Motrena iz nasljeđa pravne dogmatike, koja je zaokupljena ponajprije sistematskim tumačenjem prava jer joj je predmet uslijed obrazloženja i nedostupnosti sudskih i upravnih te poslovnih odluka oskudan, PPA može izgledati nespojivim s romansko-germanskim pravnim rasuđivanjem. Međutim, problemsko usmjerenje, koje je PPA preuzeo iz američkog pragmatizma ${ }^{77}$, te odlučujuće određuje funkcije PPA-a (supra AA) blisko je medicinskoj dogmatici koja je uzor pravnoj (supra 3.2.7). Štoviše, PPA prihvaća niz pojmova i postupaka kontinentalnoeuropskoga pravnog nasljeđa, osobito rimski kondikcijski postupak kao obrazac svakoga društvenog međudjelovanja i Weberov historijski institucionalizam kao okvir objašnjenja uvjeta i posljedica društvenog djelovanja. ${ }^{78}$ Napokon, rastući broj PPA-istraživanja raznorodnih problema dograđuje i teorijsko-metodologijski okvir PPA-a te pokazuje da pravnopolitička analiza nije program nego postignuce koje može biti poticajno. ${ }^{79}$

77 Lasswell, H. D., A Pre-View of Policy Sciences, Elsevier, Amsterdam, 1971., str. XIII - XIV. Vidi Dewey, J., Reconstruction of Philosophy, Henry Holt and Co, New York, 1920., str. $13-18$.

78 Padjen, I., Catholic Theology in Croatian Universities: Between the Constitution and the Treaty; A Policy Oriented Inquiry, u: Vukas, B.; Šošić, T. (eds.), International Law: New Actors, New Concepts, Continuing Dilemmas: Liber Amicorum Božidar Bakotić, Nijhoff, Leiden, 2009., str. 13 - 40, na str. 38 - 40.

Osobito: ibid.; Idem, A Policy Oriented Search for Basic European Values, Dignitas: The Slovene Journal of Human Rights, no. 70-72, 2016., str. 115 - 137; Idem, Religious Rights in Croatia: Legal Regulation of Culturalism, u: Wojcjechowski, B.; Bekrycht, T.; Cern, K. M. (eds.), The Principle of Equality as a Fundamental Norm in Law and Political Philosophy, Wydawnictwo Uniwersytetu Lodzkiego, Lodz, 2017., str. 119 - 154; Lalić Novak, G.; Padjen, I., Europeanisation of Asylum: From Sovereignty via Harmony to Unity, Politička misao / Croatian Political Science Review, vol. 46, no. 5, 2009., str. 75 - 101; Lalić Novak, G., Razvoj sustava azila u Hrvatskoj, Društveno veleučilište u Zagrebu, 2010.; Idem, Azil: pravni i institucionalni aspekti, Pravni fakultet Sveučilišta u Zagrebu, Zagreb, 2016. 


\section{(4) Zaključak}

Ovaj prinos otpravio je trostruku zadaću. Prvo, ukratko je izložio vlastite pretpostavke, od kojih su nosive da je svaka društvena pojava jedinstvena, zaključci su o njima po sličnosti, a pojmovi idealni tipovi. Drugo, pobliže je izložio pretpostavke i uvjete Kantorowiczeve diobe znanosti o pravu (formalizam vs. finalizam; obrazlaganje i objava sudskih presuda; Rickertova filozofija znanosti). Treće i najvažnije, pokazao je da je Kantorowiczevu diobu primjereno shvatiti kao diobu jedinstvene pravne znanosti u četiri funkcije.

Pravna dogmatika, koja se uobičajeno poima kao disciplina koja tumači i sistematizira pozitivno pravo radi olakšavanja njegove primjene, ne samo da opravdava (po nakani: na temelju izvora pozitivnog prava) nego i objašnjava (očito: utjecaj postojeće sudske prakse na buduću). Stoga je trajno otvoreno pitanje u kojoj je mjeri odvojiva od, s jedne strane, opće historije i drugih posebnih historija (npr. politike, religije) i, s druge, teorijskih društvenih znanosti (npr. sociologijskih, ekonomskih), koje objašnjavanju svoje predmete na temelju obuhvatnih zakona (vidi t. 3.2.4 - 3.2.5).

Pravna historija, koja se nerijetko drži humanističkom disciplinom, neizostavni je sastojak pravnih znanosti: historijska metoda nosiva je i za pravne dogmatike; predmete historije prava moguće je prepoznati i odrediti samo pravnodogmatski; značajan dio pravne povijesti objašnjiv je ponajprije unutrašnjim pravnim uzrocima (vidi t. 3.3.2).

Teorija prava istražuje temeljne pravne pojmove, kao što su to pojam pravnog subjekta ili pojam subjektivnog prava, čime je (iako nikada potpuno) metadogmatika. Središnji joj je pojam pravnog sistema. Takoreći prirodno pojam je konkretnoga pravnog sistema, primjenjiv i na njemu slične. Tako teorijskopravni pojam pravnog sistema nije praktičkofilozofijski, iako se teorija prava oslanja na filozofiju (vidi t. 3.4.1 - 3.4.2, 3.4.4).

Pravna politika, tj. istraživanje de lege ferenda, potrebno je svakoj primjeni prava jer primjena uključuje i stvaranje prava. Policy oriented jurisprudence najobuhvatniji je i najrazrađeniji okvir pravne politike. Prilagođen je kao pravnopolitička analiza (PPA) kontinentalnoeuropskim pravima te primijenjen u više hrvatskih pravnoznanstvenih radova. 


\section{LITERATURA}

Aarnio, A., Denkweisen der Rechtswissenschaft, Springer, Wien, 1979.

Adomeit, K., Rechtswissenschaft, u Görlitz, A. (ur.), Handlexikon zur Rechtswissenschaft, Rowohlt, Reinbek bei Hamburg, 1972., str. 369-371.

Akvinski, T., Suma protiv pogana, prij., Kršćanska sadašnjost, Zagreb, 1994.

Akvinski, T., Summa Theologica, u Idem, Izbor iz djela, 2 sv., prij., Naprijed, Zagreb, 1990.

Albert, H. et al. (ur.), Rechtstheorie als Grundlagenwissenschaft der Rechtswissenschaft, Bertelsmann, Düsseldorf, 1972. = Jahrbuch der Rechtssoziologie und Rechtstheorie, Bd. 2, 1972.

Alexander, J. C., Theoretical Logic in Sociology, vol. 1, University of California Press, Berkeley CA, 1982.

Apel, K.-O., Analytic Philosophy of Language and the Geisteswissenschaften, Reidel, Dordrecht, 1968.

Bakotić, B., Katedra za međunarodno pravo - povijesna skica, u Pavić, Ž. (ur.), Pravni fakultet u Zagrebu 1776-1996, knj. II., Prilozi za povijest katedri i biblioteke, sv. 1., Pravni fakultet, Zagreb, 1996, str. 325-328.

Baldus, M., Die Einheit der Rechtsordnung: Die Bedeutung einer juristischen Formel in Rechtstheorie, Zivil- und Strafrechtswissenschaft im 19. und 20. Jahrhunderts, Duncker \& Humblot, Berlin, 1995.

Björne, L., Deutsche Rechtssysteme im 18. und 19. Jahrhundert, Verlag Rolf Gremer, Ebelsbach, 1984.

Bobbio, N., 'Sein' and 'Sollen' in Legal Science, Archiv für Rechts- und Sozialphilosophie, Beiheft N. F., vol. 6, 1971., str. 7-32; prij. Bitak i trebanje u pravnoj znanosti, u Idem, Eseji iz teorije prava, prij., Logos, Split, 1988, str. 31-50.

Broeckmöller, A., Die Entstehung der Rechtstheorie im 19. Jahrhundert in Deutschland, Nomos, Baden-Baden, 1997.

Bumke, C., Rechtsdogmatik: Eine Disziplin und ihre Arbeitsweise. Zugleich eine Studie über das rechtsdogmatische Arbeiten Friedrich Karl von Savignys, Mohr, Tübingen, 2017.

Caenegem, R. C., Judges, Legislators, and Professors: Chapters in European Legal History, Cambridge University Press, Cambridge UK, 1987.

Capeletti, M.; Merryman, J. H.; Perill, J. M., The Italian Legal System: An Introduction, Stanford University Press, Stanford CA, 1967.

Casper, G., Juristischer Realismus und politische Theorie im amerikanischen Rechtsdenken, Duncker \& Humblot, Berlin, 1967. 
D'Amato, A. A., The Concept of Custom in International Law, Cornell University Press, Ithaca NY, 1971.

Dewey, J., Reconstruction of Philosophy, Henry Holt and Co, New York, 1920.

Dreier, R., Zum Selbstverständnis der Jurisprudenz als Wissenschaft (1971), u Idem, Recht-Moral-Ideologie: Studien zur Rechtstheorie, Suhrkamp, Frankfurt a. M., 1981, str. 48-69.

Dubischar, R., Einführung in die Rechtstheorie, Wissenschaftliche Buchgesellschaft, Darmstadt, 1983.

Dworkin, R., Taking Rights Seriously, new impr. Duckworh, London, 1978.

Engisch, K., Die Einheit der Rechtsordnung, Carl Winters, Heidelberg, 1935.

Esser, J., Grundsatz und Norm in der richterlichen Fortbildung des Privatrechts, Mohr, Tübingen, 1956.

Felix, D., Einheit der Rechtsordnung: Zur verfassungsrechtlichen Relevanz einer juristischen Argumentationsfigur, Mohr, Tübingen, 1998.

Feteris, E., Advancing Reason to Its Further Borders, u Pattaro; E.; Roversi, C. (eds.), Legal Philosophy in the Twentieth Century: The Civil Law World, t. 2, Main Orientations and Topics, Springer, Dordrecht, 2016, str. 665-708.

Finnis, J. (ed.), Natural Law, Dartmouth, Aldershot, 1991.

Flores, B., Legisprudence: The Problems and Limits of Legislation (21 Aug. 2018); https://www.researchgate.net/publication/316536515_Legisprudence_the_ Forms_and_Limits_of_Legislation (pristup 29.04.2019.).

Fuller, L. L., Human Purpose and Natural Law, Natural Law Forum, vol. 3, 1956. str. 68-76.

Gény, F., Méthode d'interprétation et sources en droit privé positif, 2 t., lere ed. 1899; 2ème ed. 1919, réimpr. L.G.D.J., Paris, 1954.

Grawert, R., Recht positives; Rechtspositivismus, u Historisches Wörterbuch der Philosophie, Bd. 8, Schwabe, Basel, 1992, str. 234-242.

Herberger, M., Dogmatik: Zur Geschichte von Begriff und Methode in Medizin und Jurisprudenz, Klostermann, Frankfurt a. M., 1981.

Herberger, M., Rechtsdogmatik, u Historisches Wörterbuch der Philosophie, Bd. 8, Schwabe, Basel, 1992, str. 266-271.

"Hermann Kantorowicz (1877-1940): the battle for legal science" conference, University of Helsinki, (October 25th-26th 2018); https://www.helsinki.fi/ en/news/society-economy/hermann-kantorowicz-1877-1940-the-battle-forlegal-science-conference (pristup 01.12.2018.)

Hoecke, M. v., What is Legal Theory?, Acco, Leuven, 1995. 
Jahr, G.; Maihofer, W. (Hrsg.), Rechtstheorie: Beiträge zur Grundlagendiskussion, Klostermann, Frankfurt a. M., 1970.

Jahr, G., Zum Verhältnis von Rechtstheorie und Rechtsdogmatik, u Jahr, G.; Maihofer, W. (Hrsg.), Rechtstheorie: Beiträge zur Grundlagendiskussion, Klostermann, Frankfurt a. M., 1970., str. 303-311.

Kantorowicz, H. U., Der Kampf um die Rechtswissenschaft. Von Gnaeus Flavius, Winter, Heidelberg, 1906.

Kantorowicz, H. U., Die Epochen der Rechtswissenschaft, Die Tat, Bd. 6, H. 4, 1914., str. 345-361

Kantorowicz, H. U., Methodenreform und Justizreform, Deutsche Richterzeitung, Bd. 3, H. 11, I Juni 1906, str. 349-356.

Kantorowicz, H. U., Rechtshistorische Schriften, hrsg. V. Coing, H.; Immel, G., Mueller, Karlsruhe, 1970.

Kantorowicz, H. U., Rechtswissenschaft und Soziologie, Mohr, Tübingen, 1911.

Kantorowicz, H. U., Some Rationalism about Realism, Yale Law Journal, vol. 43, no. 8, 1934., str. 1240-1253.

Kantorowicz, H. U., Staatsauffassungen: Eine Skize, Jahrbuch fuer Soziologie, Bd. 1, 1925., str. 101-114.

Kantorowicz, H. U., Zur Theorie des Sozialliberalismus, Schmollers Jahrbuch, Bd. 28, 1904., str. 673-682.

Kelsen, H., General Theory of Law and State, tr., Russell \& Russell, New York, 1961.

Koriath, H., Kausalität und objektive Zurechnung, Nomos, Baden-Baden, 2007.

Koschaker, P., Europa und das Römische Recht, 2. Aufl., Beck, München, 1953, str. 108-09.

Lalić Novak, G., Azil: pravni i institucionalni aspekti, Pravni fakultet Sveučilišta u Zagrebu, Zagreb, 2016.

Lalić Novak, G.; Padjen, I., Europeanisation of Asylum: From Sovereignty via Harmony to Unity, Politička misao / Croatian Political Science Review, vol. 46, br. 5, 2009., str. 75-101.

Lalić Novak, G., Razvoj sustava azila u Hrvatskoj, Društveno veleučilište u Zagrebu, Zagreb, 2010.

Lanović, M., Uvod u pravne nauke, 2. izd., Državni tiskarski zavod, Zagreb, 1942.

Lasswell, H. D.; McDougal, M. S., Jurisprudence for a Free Society: Studies in Law, Science and Policy, 2 vols., Kluwer Law International, Alphen aan den Rijn, 1992.

Lasswell, H. D., A Pre-View of Policy Sciences, Elsevier, Amsterdam, 1971. 
Leiter, B., American Legal Realism, u Patterson, D. (ed.), Guide to A Companion to Philosophy and Legal Theory, $2^{\text {nd }}$ ed., Wiley-Blackwell, Chichester UK, 2010, str. 249-266.

Lyons, J., Semantics, vol. 1, Cambridge University Press, Cambridge UK, 1979.

Maihofer, W., Rechtstheorie als Basisdisziplin der Jurisprudenz, u Albert, H. et al. (ur.), Rechtstheorie als Grundlagenwissenschaft der Rechtswissenschaft, Bertelsmann, Düsseldorf, 1972., str. 51-78.

Martinović, I., Problem uzročnosti u kaznenom pravu, Hrvatski ljetopis za kazneno pravo i praksu, vol. 19, br. 1, 2012., str. 75-104.

Mayda, J., François Geny and Modern Jurisprudence, Louisiana State University Press, Baton-Rouge, 1978.

Meder, S., Missverstehen und Verstehen: Savignys Grundlegung der juristischen Hermeneutik, Mohr, Tübingen, 2004.

Mill, J. S., A System of Logic, $8^{\text {th }}$ ed., Harper \& Brothers, New York, 1882.; http:// www.gutenberg.org/license.

Myres Smith McDougal: Appreciations of an Extraordinary Man, Yale Law School, New Haven CT, 1999.

Naša zakonitost: časopis za pravnu teoriju i praksu; prilog: Pregled sudske prakse, 1972.-1989.

Nicholas, B., Le language des biens dans le common law, Archives de philosophie du droit, vol. 24, Les biens et les choses en droit, Sirey, Paris, 1979., str. 55-63.

Nörr, D., Savignys philosophische Lehrjahre: Ein Versuch, Klostermann, Frankfurt a. M., 1994.

Padjen, I., Catholic Theology in Croatian Universities: Between the Constitution and the Treaty; A Policy Oriented Inquiry, u Vukas, B.; Šošić, T. (eds.), International Law: New Actors, New Concepts, Continuing Dilemmas: Liber Amicorum Božidar Bakotic, Nijhoff, Leiden, 2009., str. 13-40.

Padjen, I., Metodologija pravne znanosti: pravo i susjedne discipline, Pravni fakultet Sveučilišta u Rijeci, Rijeka, 2015.

Padjen, I., A Policy Oriented Search for Basic European Values, Dignitas: The Slovene Journal of Human Rights, no. 70-72, 2016., str. 115-137.

Padjen, I., Religious Rights in Croatia: Legal Regulation of Culturalism, u Wojcjechowski, B.; Bekrycht, T.; Cern, K. M. (eds.), The Principle of Equality as a Fundamental Norm in Law and Political Philosophy, Wydawnictwo Uniwersytetu Lodzkiego, Lodz, 2017., str. 119-154.

Pattaro, E. (gen. ed.), A Treatise of Legal Philosophy and General Jurisprudence, vol. 13, Springer, Dordrecht, 2005.-2016. 
Pawlowski, H.-M., Das Studium der Rechtswissenschaft, Mohr, Tübingen, 1969.

Peczenik, A., Scientia Juris: Legal Doctrine as Knowledge of Law and as a Source of Law, Springer, Dordrecht, 2007.

Perić, B., Struktura prava, 1. dio, 6. izd., Sveučilišna naklada Liber, Zagreb, 1978.

Petrović, G., Logika, 1l. izd., Školska knjiga, Zagreb, 1977.

Priester, J.-M., Rechtstheorie als analytische Wissenschaftstheorie, u Jahr, G.; Maihofer, W. (Hrsg.), Rechtstheorie: Beiträge zur Grundlagendiskussion, Klostermann, Frankfurt a. M., 1970., str. 13-61.

Pokrovac, Z., Slobodno stvaranje prava prava: Hermann U. Kantorowicz i slobodnopravni pokret, Breza, Zagreb, 2018.

Pravilnik o znanstvenim i umjetničkim područjima poljima i granama, Narodne novine, br. 118/2009 118/2009, 82/2012, 32/2013 i 34/2016.

Raz, J., The Concept of a Legal System, Oxford University Press, Oxford, 1970.

Rickert, H., Die Grenzen der naturwissenschaftlichen Begriffsbildung, Mohr, Freiburg i. B., 1902.

Rickert, H., Kulturwissenschaft und Naturwissenschaft, Mohr, Freiburg i. B., 1899.

Rickert, H., Zur Lehre von der Definition, Wagner Druck, Freiburg i. B., 1888.

Ritzer, G.; Smart, B. (eds.), Handbook of Social Theory, SAGE, London, 2003.

Rüthers, B., Rechtstheorie: Begriff, Geltung und Anwendung des Rechts, Beck, München, 1999.

Saegesser, B., Der Idealtypus Max Webers und der naturwissenschaftliche Modellbegriff, Druckerei Birkhaeuser, Basel, 1975.

Sartor, G., Legal Reasoning: A Cognitive Approach to the Law, Springer, Dordrecht, 2005.

Savigny, F. C. v., Vorlesungen ueber juristische Methodologie 1802-1842, hrsg. u. eing. v. Mazzacame, A., Klostermann, Frankfurt a. M., 2004.

Schwarzenberger, G., The Inductive Approach to International Law, Stevens \& Sons, London, 1965.

Simon, D., Rechtsgeschichte, u Görlitz, A. (Hrsg.), Handlexikon zur Rechtswissenschaft, Rowohlt, Reinbek bei Hamburg, 1972., str. 314-318.

Sirotković, H., Organizacija i djelovanje Fakulteta od 1918. do danas, u Filipović, N.; Sokol, S. (ur.), Pravni fakultet u Zagrebu 1945-1980, Pravni fakultet, Zagreb, 1980., str. 50-51.

Stephanitz, D. v., Exakte Wissenschaften und Recht. Der Einfluss von Naturwissenschaft und Mathematik aufRechtsdenken und Rechtswissenschaft in zweieinhalb Jahrtausenden. Ein historischer Grundriss, Walter de Gruyter, Berlin, 1970. 
Stith, R., Can Practice Do Without Theory? Differing Answers in Western Legal Education, Archiv für Rechts- und Sozialphilosophie, Bd. 80, H. 3, 1994. str. 426-435.

Tucak, I., Hohfeldova analitička teorija prava, Pravni fakultet Sveučilišta J. J. Strossmayer, Osijek, 2016.

Turner, B. S. (ed.), Blackwell Companion to Social Theory, Blackwell, Oxford, 1996.

Udruga hrvatskih sudaca, Sudska praksa; http://www.uhs.hr/index.php/linkovi/ supra

Visković, N., Pojam prava: prilog integralnoj teoriji prava, 2. izd., Logos, Split, 1983.

Vrhovni sud Republike Hrvatske, Sudska praksa; https.//sudskapraksa.cspvsrh. hr/home

Watson, A., The Evolution of Law, The Johns Hopkins University Press, Baltimore, 1985.

Weber, M., Die 'Objektivität' sozialwissenschaftlicher und sozialpolitischer Erkenntnis, u Idem, Gesammelte Aufsätze zur Wissenschaftslehre, 3. Aufl. hrsg. v. Winckelmann, J. Mohr \& Paul Siebeck, Tübingen, 1968.

Wieacker, F., Privatrechtsgeschichte der Neuzeit, 2. Aufl., Vandenhoek \& Ruprecht, Göttingen, 1967. 
Summary

\section{Ivan Padjen*}

\section{LEGAL SCIENCE: KANTOROWICZ'S DIVISION INTO DISCIPLINES OR FUNCTIONS?}

Is Herman U. Kantorowicz's classification of legal disciplines - which includes general legal science, legal dogmatics, legal history, sociology of law, philosophy of law, and legal policy - a division of scholarly knowledge of law into distinct disciplines/sciences or into intertwined functions of a single scholarly discipline/science? The question is prompted by the book written by Zoran Pokrovac entitled Slobodno stvaranje prava: Hermann U. Kantorowicz i slobodnopravni pokret (Free Law: Hermann U. Kantorowicz and the Free Law Movement ) and published by "Breza" and the Faculty of Law of the University of Split in 2018.

Answering this question may assist Croatian legal scholars in finding standards of scholarly excellence, especially of research de lege ferenda.

This paper offers an answer in three steps. The first is the recognition that scholarly practices differ considerably, which means that the question may be answered only by construing and correlating ideal types of legal disciplines / functions that are compatible with Kantorowicz's general ideas, prominent interpretations of legal scholarship, and Croatian mainstream legal scholarship since. The second step provides a context of Kantorowicz's classification, focusing upon the publication of judicial decisions as a trigger of the Free Law Movement and a task that the Croatian legal order has yet to complete. The third step is the claim that Kantorowicz has in all probability considered scholarly knowledge of law to be a set of intertwined functions. To substantiate this claim, the bulk of the paper construes ideal types of legal dogmatics, legal history, legal theory, and, as the most complex and promising integration of the functions, legal policy modelled on Lasswell and McDougal's Policy Oriented Jurisprudence. The assumption that is stated but not discussed is that there is no clear-cut borderline between legal scholarship and other scholarly disciplines, most notably sociology, economics, psychology and philosophy.

Keywords: Hermann U. Kantorowicz, legal science, legal dogmatics, legal history, legal theory, legal policy

Ivan Padjen, Ph. D., Professor (ret.), Faculty of Law, University of Rijeka, Hahlić 6, Rijeka; Faculty of Political Science, University of Zagreb, Lepušićeva 6, Zagreb; ivan.l.padjen@gmail.com;

ORCID ID: orcid.org/ 0000-0001-7606-2337 
